The Effect of Different Dripper Properties on Entomopathogenic Nematode Application in Drip Irrigation

\author{
Hilal ERDOĞAN1, Tufan Can ULU2 ${ }^{2}$, Hayrettin KUŞÇU ${ }^{3}$ \\ ${ }^{1,3}$ Bursa Uludağ University, Faculty of Agriculture, Department of Biosystems Engineering, Bursa, Turkey, ${ }^{2}$ Bilecik Şeyh Edebali University, \\ Faculty of Agriculture and Natural Sciences, Department of Plant Protection, Bilecik, Turkey \\ 1https://orcid.org/0000-0002-0387-2600, ${ }^{2}$ https://orcid.org/0000-0003-3640-1474, ${ }^{3}$ https://orcid.org/0000-0001-9600-7685 \\ 凶: tufan.ulu@bilecik.edu.tr
}

\section{ABSTRACT}

There are many types of drippers with different flow path length, flow path shape and filtration surface. EPN delivery performance of the most commonly used four different types of drippers (in-line short path, in-line long path, in-line cylindrical and on-line button) was examined with a drip irrigation system in laboratory conditions. Under four different pressures $(0.5,1,1.5,2$ bar), EPNs were applied to 1-liter beakers with irrigation system and discharged nematodes were counted under a stereomicroscope. The effect of pressure on application and EPN mortality were also determined. The results showed that there were significant differences between the discharge ratio of EPNs from drippers. Among the four drippers, on-line button dripper sustained the highest and fastest discharge ratio. Pressure alone had no significant effect on delivering EPNs. However, it should be considered that long pressure exposure may harm EPNs. Regarding our results, different irrigation drippers have significantly different effects on EPN discharge ratio. Therefore, optimizing drip irrigation systems for EPN applications may increase their performance.

\section{Research Article}

$\begin{array}{ll}\text { Article History } & \\ \text { Received } & : 11.03 .2019 \\ \text { Accepted } & : 30.09 .2019\end{array}$

\section{Keywords}

Beneficial nematode

Drip irrigation

Pressure

Dripper

Biopesticide

\title{
Damla Sulamada Farklı Damlatıcı Özelliklerinin Entomopatojen Nematod Uygulamasına Etkisi
}

\section{ÖZET}

Damla sulamada kullanılan damlatıcıların akış yolu uzunluğu, akış yolu şekli, damlatıcı debisi vb. farklı özellikleri bulunmaktadır. Bu çalışmada damla sulamada yaygın olarak kullanılan dört farklı damlatıcının (içten geçik kısa akış yollu damlatıcı, içten geçik uzun akış yollu damlatıcı, içten geçik silindir tipli damlatıcı, üstten geçik katif damlatıcı) EPN uygulamasındaki performansları laboratuvarda kurulan damla sulama sistemiyle karşılaştırılmıştır. Dört farklı basınç altında (0.5, 1, 1.5, 2 bar) EPN'ler 1 litrelik beherlere uygulanmış ve beherlerdeki EPN'ler süzülerek mikroskop altında sayılmıştır. Çalışmada basıncın ve uygulamaya ve EPN üzerinde ölümcül etkisi de incelenmiştir. Sonuçlar değerlendirildiğinde farklı damlatıcılardan çıkan EPN miktarları arasında önemli farklılıklar olduğu tespit edilmiştir. Denemelerde üstten geçik katif damlatıcı ile yapılan uygulamalarda en fazla ve en hızlı EPN çıkışı olduğu tespit edilmiştir. Basıncın tek başına, uygulamaya ve EPN üzerine herhangi bir etkisinin olmadığı tespit edilmesine rağmen uzun süreli yüksek basinca maruz kalan EPN'lerin zarar görebileceği göz önünde bulundurulmalıdır. Çalışma sonuçları incelendiğinde farklı damlatıcıların EPN uygulamasında farklı çıkış oranları gösterdiği belirlenmiştir. Bu nedenle gelecekte damla sulama sistemlerinin EPN uygulaması üzerine optimize edilmesi ile başarı şansının artacağı düşünülmektedir.

\section{Araştırma Makalesi}

$\begin{array}{ll}\text { Makale Tarihçesi } \\ \text { Geliş Tarihi } \quad: 11.03 .2019 \\ \text { Kabul Tarihi } & : 30.09 .2019\end{array}$

Anahtar Kelimeler
Faydalı nematodlar
Damla sulama
Basınç
Damlatıcı
Biyopestisit

To Cite: Erdoğan H, Ulu TC, Kuş̧̧ H 2020. The Effect of Different Dripper Properties on Entomopathogenic Nematode Application in Drip Irrigation. KSU J. Agric Nat 23 (1): 230-236. DOI:10.18016/ksutarimdoga.vi.533723. 


\section{INTRODUCTION}

Organisms used in biological control are known as biocontrol agents, and Entomopathogenic Nematodes (EPNs) have great potential within these agents (Lacey et al., 2015). EPNs are soil-dwelling obligate endoparasitic organisms, which have lethal effect on agricultural insect pests (Kaya and Gaugler, 1993). EPNs have a broad host range; they are safe to vertebrates, plants, and most other non-target organisms (Peters, 1996). They can be mass produced in bioreactors (Ehlers, 2001; Shapiro-Ilan et al., 2012), and can be easily applied with conventional sprayers (Gan-Mor and Matthews, 2003; Wright et al., 2005; Sayinci and Bastaban, 2008). EPNs are resistant to shear stress, and they can survive under high pressure (Fife et al., 2003). Hence, previous studies showed that some EPN species can resist around 14 bar (Wright et al., 2005). Different studies showed that EPNs could also persist in soil averagely 4-5 months, even up to 22 months (Susurluk and Ehlers, 2008).

There are many application techniques of EPNs. They can be applied with standard sprayers and conventional machines. Applications with hand pumps, spray cannons, and drip irrigation are mostly suggested. Moreover, in different studies, EPNs were applied with spinning discs, micro-injectors, subsurface syringes, different irrigation systems and other application types such as cadaver or serum-like application (Conner et al., 1998; Wennemann et al., 2003; Wang et al., 2009; Raja et al., 2015). These techniques are generally not feasible and their application success is low. Some studies revealed that more than half of the EPNs jammed in irrigation systems and could not be delivered to the soil (Conner et al., 1998; Wennemann et al., 2003; Wang et al., 2009; Arrington et al., 2016).

EPNs are a niche market within biological control. Even though their persistence is more prolonged than chemical pesticides, periodical EPN applications are suggested to achieve better results. Production, formulation, storage and transport of EPNs are laborious and expensive processes, like other biological products. The shelf life of commercial EPN products are usually about several months, and they must be applied freshly for better biological control (Grewal, 2002). Thus, EPNs are considered as valuable products and must be used effectively (Wright et al., 2005).

Because of the negative sides of other agricultural spraying tools, a more suitable application method should be developed or existing techniques should be optimized for EPN application. Thus, our study aimed to examine the performances of four different irrigation drippers for delivering EPNs under four different pressures with a lab-scale drip irrigation system. Additionally, the correlation between water outlet and EPN discharge was also recorded. It is expected that this study will sort out useful knowledge about drip irrigation optimization for EPN application.

\section{MATERIAL and METHOD}

\section{Entomopathogenic Nematode}

Entomopathogenic nematode Heterorhabditis bacteriophora $\mathrm{HbH}$ strain was used in all experiments. This strain is a hybrid of Turkish EPN isolates which were isolated from different climatic regions of Turkey. $H$. bacteriophora is a common EPN species, and its length is averagely about 600 microns (Stock and Hunt, 2005), which makes it compatible for most drippers.

EPNs were reproduced using in vivo method with greater wax moth Galleria mellonella (Lepidoptera: Pyralidae) (Kaya and Stock, 1997). Each larva was infected with 50 IJs in silver sand and incubated at 24 ${ }^{\circ} \mathrm{C}$. Four days after incubation, dead larvae were transferred to White Trap. Approximately 50.000 fresh IJs harvested from White Trap and transferred into a $50 \mathrm{ml}$ falcon tube filled with tap water. One-week-old populations were used for trials. Mortality of the populations was generally lower than $1 \%$.

\section{Drippers and Driplines}

Four different common types of drippers were chosen for the lab scale irrigation system. These drippers were three types of in-line drippers (short path, long path, cylindrical) and one on-line button dripper. In-line short and long path drippers were used with flat, inline cylindrical and on-line button drippers were used with round pipes. All pipes were polyethylene and 16 $\mathrm{mm}$ in diameter. The distance between drippers was $20 \mathrm{~cm}$ for short path, cylindrical and button, and $30 \mathrm{~cm}$ for long path dripper. Dripper details and images can be seen in Table 1 and Fig. 1, respectively.

\section{Application}

All trials were conducted with lab scale irrigation system. The irrigation system was connected to tap water $\left(\mathrm{EC}=0.3 \mathrm{dS} \mathrm{m}^{-1}, \mathrm{pH}=8.3\right.$ and temperature of 20 ${ }^{\circ} \mathrm{C}$ ), and four different pressures $(0.5,1,1.5,2$ bar) were adjusted with a manometer connected after the tap. Tap water was able to provide more than 2.5 bar. Thus, no additional equipment was used for pressure. After adjustment of the pressure, $50.000 \mathrm{IJs}$ was transferred to the system instantly with a $50 \mathrm{ml}$ syringe just after tap connection (Curran, 1992; Wang et al., 2009). IJs were injected simultaneously with the tap water. A sample schematic of the system is given in Fig. 2 . Firstly, all trials were conducted until all 1-liter beakers were filled with water. All EPNs in beakers from both experiments were counted under a stereomicroscope using Leica S8-Apo (Leica Microsystems). Prolonged exposure to high-pressure levels may harm EPNs. Thus, an additional timing experiment was performed to reveal EPN discharge 
time. EPN discharge from each dripper was monitored for 5 minutes at 1-minute intervals with five different beakers. Before application, all pipes were flushed with tap water and new pipes were used for each replicate. For control, all EPN suspensions were injected into a beaker with the syringe and mortality ratios were checked. All experiments were replicated three times.

Table 1. Details of drippers.

Cizelge 1. Damlatıciların detayları.

\begin{tabular}{|c|c|c|c|c|c|c|}
\hline Dripper Type & Placement & $\begin{array}{l}\text { Flow Rate } \\
\mathrm{L} \mathrm{h}^{-1}\end{array}$ & $\begin{array}{l}\text { Pressure } \\
\text { Compensate }\end{array}$ & $\begin{array}{l}\text { Emitter } \\
\text { discharge } \\
\text { coefficient (k) } \\
k: \text { Damlatıcı } \\
\text { debi katsayısı }\end{array}$ & $\begin{array}{l}\text { Emitter } \\
\text { discharge } \\
\text { exponent }(\mathrm{x}) \\
x: \text { Damlatıcı } \\
\text { debi üssü }\end{array}$ & Flow regime \\
\hline Long Path & In-line & $2 *$ & - & 0.36 & 0.75 & Semi-laminar \\
\hline Short Path & In-line & 2 & + & 2.00 & 0 & Uniform \\
\hline Cylindrical & In-line & 4 & - & 1.06 & 0.58 & Turbulent \\
\hline Button & On-line & 8 & + & 10.67 & 0 & Uniform \\
\hline
\end{tabular}

*Under 1 bar operation pressure

(A)

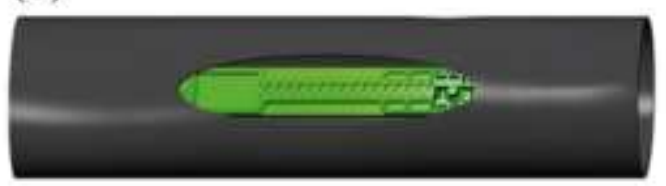

(C)

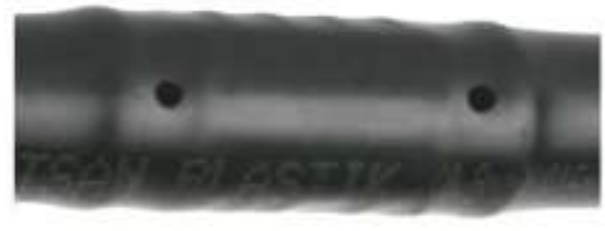

(B)

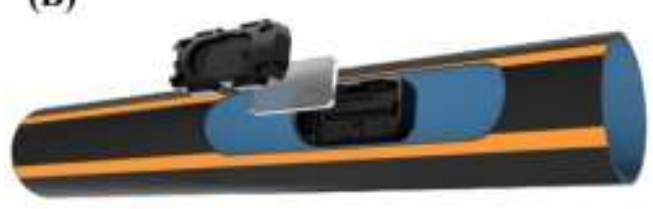

(D)

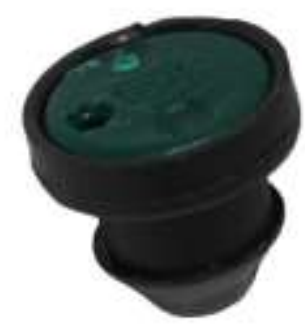

Figure 1. Real images and illustrations of drippers. (A): In-line long path, (B): In-line short path, (C): In-line cylindrical, (D): On-line button (orifice) (Images from product catalogues)

Şekil 1. Damlatıcıların gerçek görselleri ve çizimleri. (A): İçten geçik uzun yollu, (B): İçten geçik kısa yollu, (C): Silindirik, (D): Üstten geçik düğme (orifis) (Görseller ürün kataloglarından temin edilmiştir)

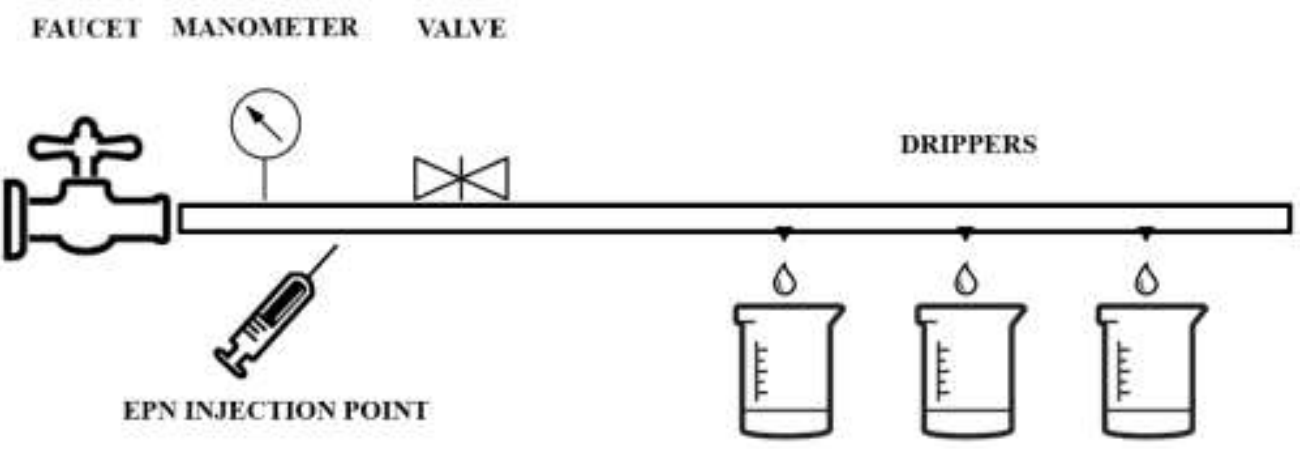

Figure 2. Sample schematic of lab scale drip irrigation system.

Şekil 2. Laboratuvar ölçekli damla sulama sisteminin şematik görüntüsü

\section{Statistical Analyses}

Results of dripper type experiment, pressure effects and dripper-pressure interaction were analyzed using
ANOVA. Least Significant Differences (LSD) test $(p<0.05)$ was used to determine the difference between applications. All statistical analyses, including 
correlations, were calculated with JMP $7.0^{\circledR}$ software.

\section{RESULTS and DISCUSSION}

\section{Drippers}

Button dripper was significantly the best one with $80.1 \%$ discharge ratio among all drippers $(\mathrm{p}<0.05)$. Long path and short path drippers delivered the least amount of EPNs (about 40\%) to beakers. The results of the dripper experiment showed in Fig. $3 \quad(F=48.25$; $\mathrm{df}=3,44 ; \mathrm{p}=<0.0001)$. The correlation between water outlet and discharged EPN in our experiment was 0.29 , which indicated a low relation (Fig. 4).

\section{Pressure and Timing Effect}

Pressure experiment results did not show any significant effect on EPN delivery $(p<0.05)$. Summary of the pressure experiment can be found in Fig. 5
$(\mathrm{F}=0.327 ; \quad \mathrm{df}=3, \quad 44 ; \mathrm{p}=0.8058)$. There were no differences between the number of EPNs at all tested pressures. Timing was also a question to find optimal application parameters. Mostly, there was no EPN discharge from drippers after 5 minutes of application. The results of the timing experiment can be found in Fig. 6.

The idea of applying EPNs with drip irrigation systems dates back to mid-1980s. Effective application of EPNs to soil becomes important to maintain sustainable biological control (Ehlers, 2005). Drip irrigation systems have a variety of different drippers, filters, pipes and pump types regarding different demands. Even the idea of delivering EPNs to soil with drip irrigation is rational; we still need specific dripper information for an effective application.

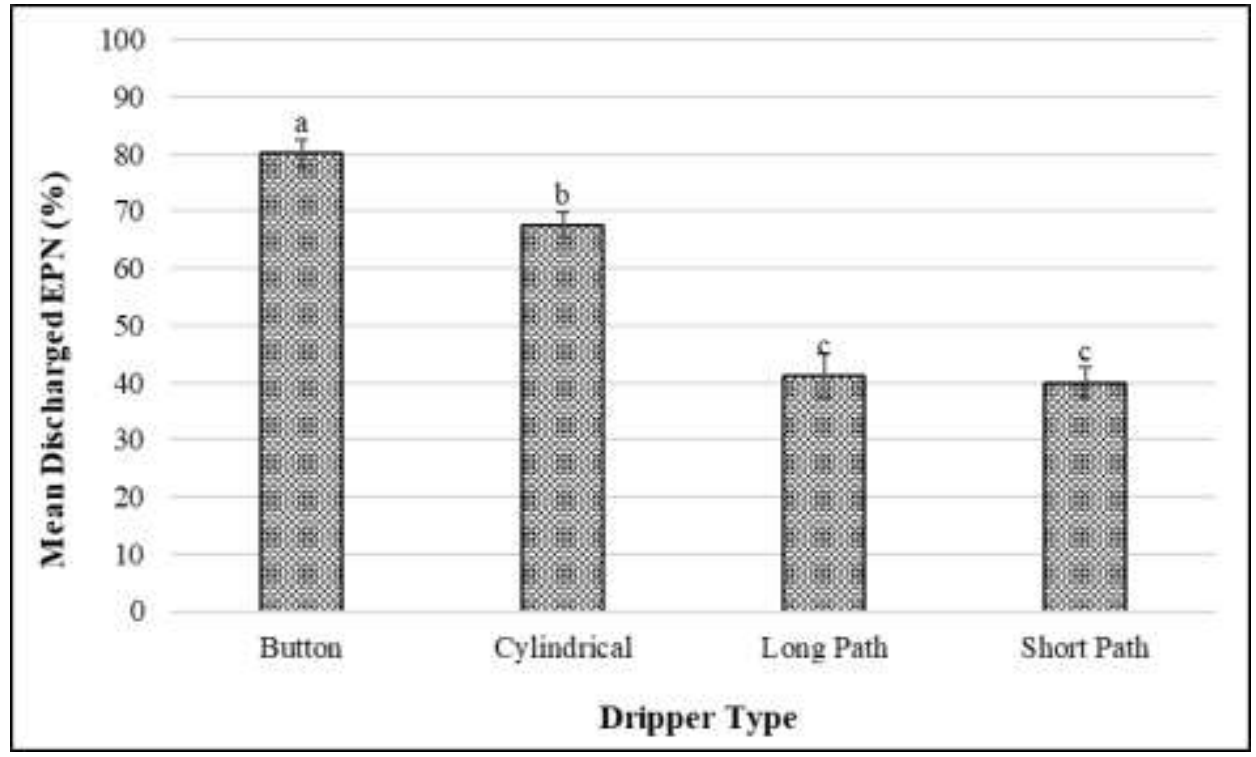

Figure 3. Dripper effects on EPN discharge.

Şekil 3. Damlatıcıların EPN çıkışına etkisi.

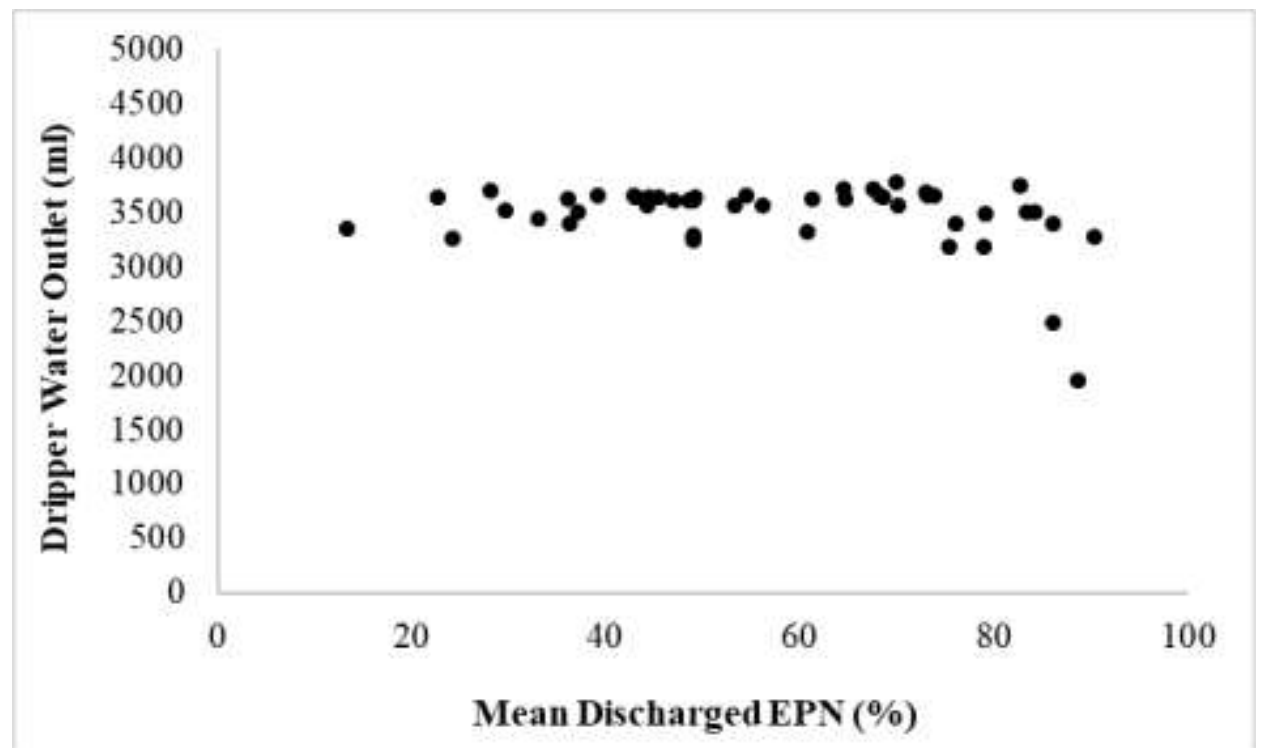

Figure 4. Correlation graph between water outlet of all drippers and mean discharged EPN ratio $(r=-0.29)$.

Şekil 4. Damlatıcılardan çıkan EPN ve su miktarının korelasyonu (r=-0.29). 


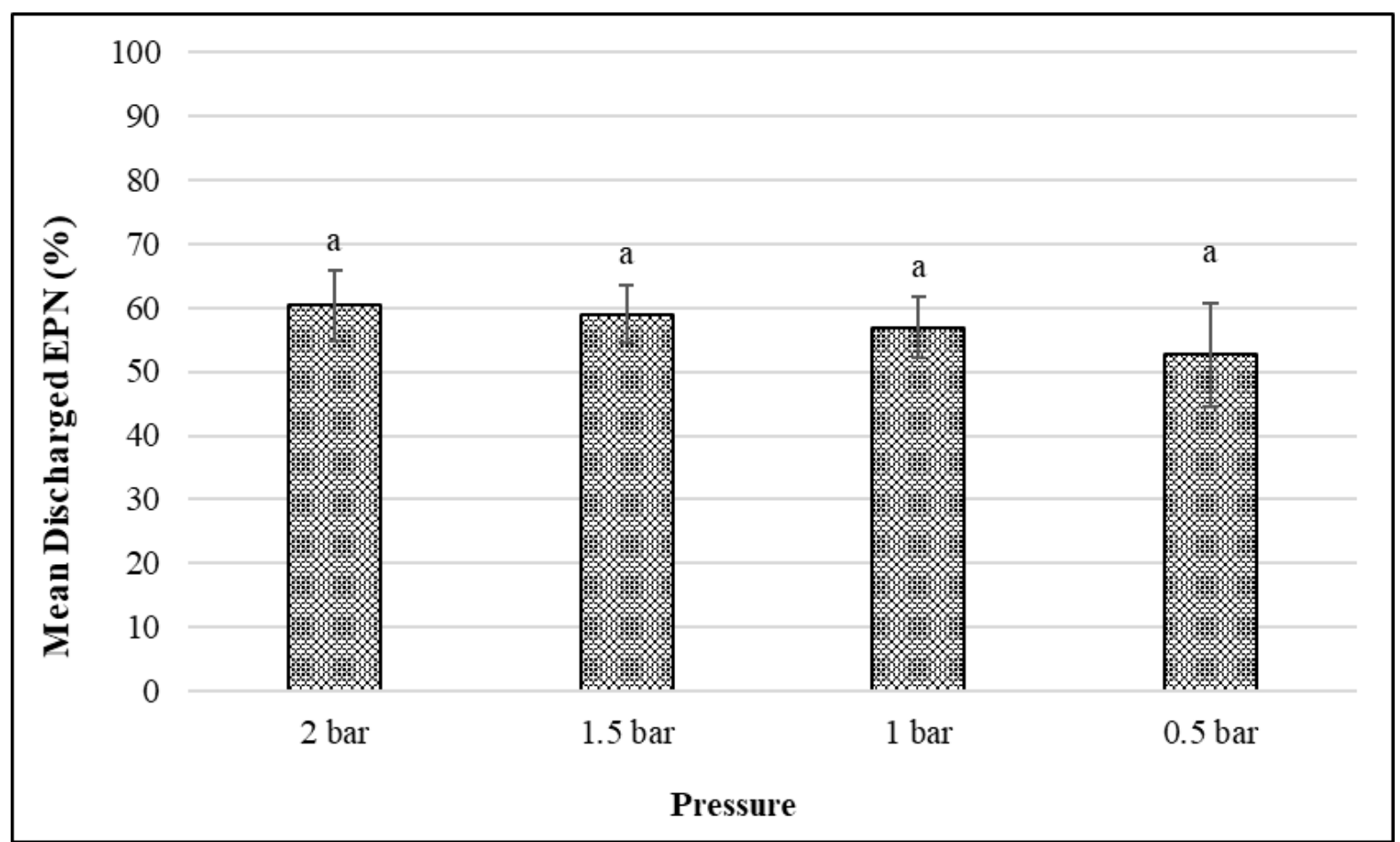

Figure 5. Effect of different pressures on EPN discharge.

Şekil 5. Farklı basınçların EPN çıkışına etkisi.

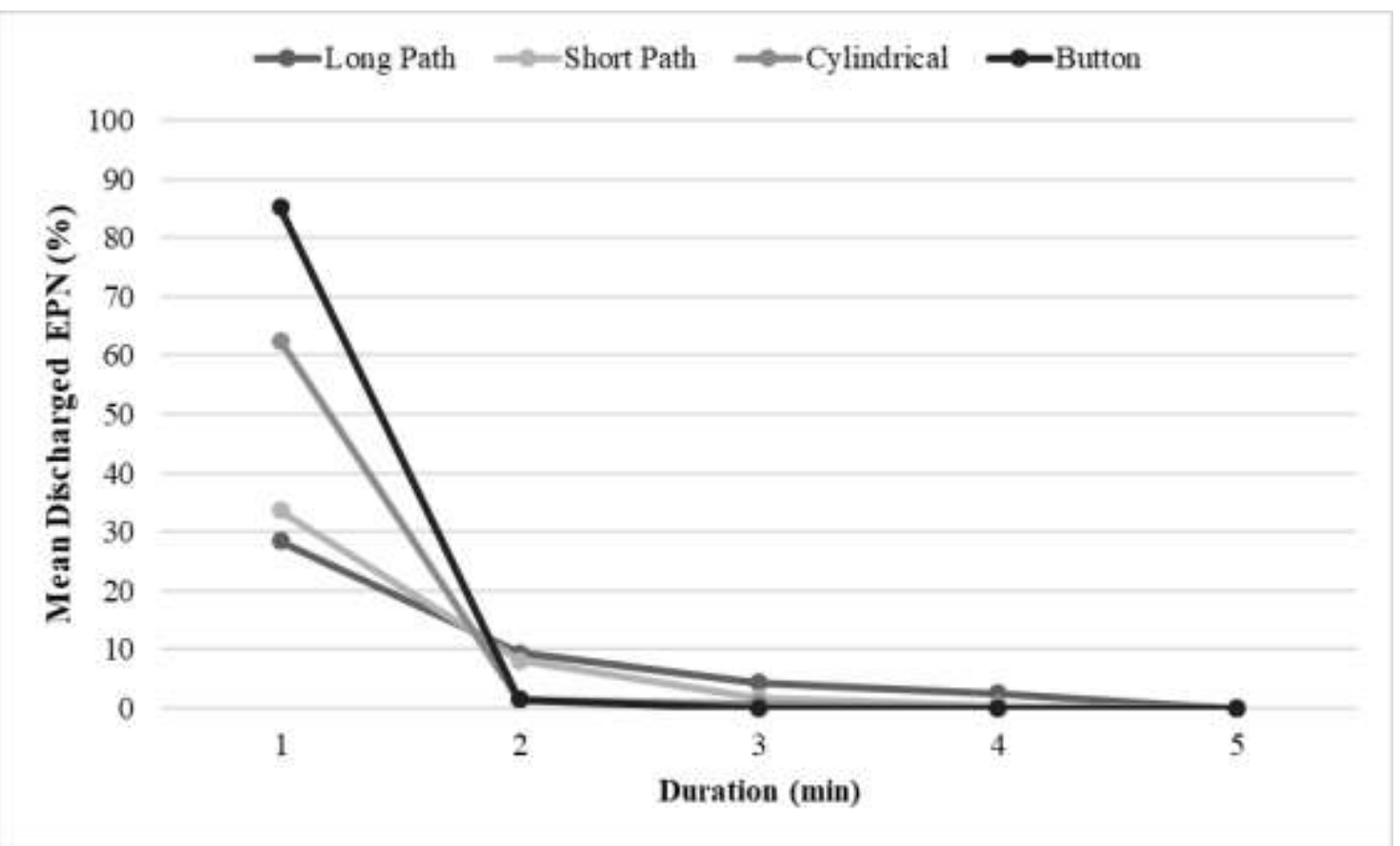

Figure 6. EPN discharge from dripper at 1 minute intervals.

Şekil 6. Damlatıcılardan bir dakikalık aralıklarla çıkış yapan EPN miktarı

One of the first studies by Reed, Reed, Creighton (1986), infective juveniles of different EPN species were applied with drip irrigation system and IJ $_{\mathbf{s}}$ successfully recovered in a uniform distribution. Following this study, center-pivot irrigation and lateral move overhead irrigation systems were used for EPN application (Wright et al., 1993; Ellsbury et al., 1996). In another study, Curran and Patel (1988) aimed an insect with EPNs applied with drip irrigation, but they also gave information about the distribution and recovery rate of EPNs through the irrigation system. They found that the nematode recovery rate was lower at the increasing distance from the EPN introduction point.

EPNs have a slightly higher density than pure water, which makes EPNs to settle down (Wright et al., 2005). Because of that, before EPN application, suspensions must be shaken. Irrigation systems with long and 
short path drippers have a low flow rate. According to initial studies, it can be easily thought that EPNs settle down in pipes and cannot exit irrigation system (Reed et al., 1986; Conner et al., 1998; Wennemann et al., 2003). To prove this, after trials, all pipes were cut in half and washed with clean tap water to see remaining EPNs. It was found that almost all remaining EPNs were alive inside the pipes. We also monitored that recovered EPNs from drippers were decreasing with the longer distance from the injection point. This result was also showed similarity with previous studies.

Movement of EPNs inside a drip irrigation system was affected by dripper types. Since in-line and on-line drippers have different pathways, filters and nozzle sizes, it is expected to see different results. Pressure is also an important parameter for drip irrigation. For general purposes, drip irrigation systems calibrated for up to 3 bar. Although results showed that there are no significant differences between pressures for delivery of EPNs, elapsed time under pressure have adverse effects on nematode biology. We monitored that even lower pressures such as 2 bar had adverse effects (such as immobility) on EPNs when the exposure time was over 20 minutes. The differing results between studies strictly depend on the strain adaptations (Fife et al., 2003). Many commercial EPN companies suggest different application pressures. These pressures can be up to 20 bar. However, long exposure to high-pressure levels may harm EPN viability and effectiveness. For example, Steinernema carpocapsae and $H$. bacteriophora can resist 20 bar, but $H$. megidis can resist 13.8 bar (Wright et al., 2005).

On the other hand, systems with cylindrical and button drippers have high flow rates. With high water flow, EPNs do not settle down and move with the water. It can be thought that high EPN delivery ratio with these drippers was a result of a high water flow rate in the system. Consequently, discharged EPN quantity is related to water flow rate inside the system, not the amount of water outlet from drippers. Wennemann et al., (2003) also investigated the distribution of EPN per ml. However, their results varied among different application sites.

An effective application of EPNs plays an important role in the success of biological control. In our study, EPN discharge ratio from long and short path drippers was below $50 \%$. This result will probably have a negative impact on the efficiency of the application. Arrington et al. (2016) examined the insecticidal effects of an EPN species and different chemicals, which were mostly applied with drip irrigation. In their study, the effect of EPN on damaged roots were not significantly different compared to control. Considering from our aspect, the low discharge ratio of EPN from drippers probably had a negative effect on their results. A similar warning was also given by
Wang et al. (2009). Their results demonstrated that suspended powders and granular agents were limited to driplines, dripper types and flow paths.

Lastly, EPNs are good option for reliable and sustainable agriculture. There are many studies on improving EPNs' mass production capacity, effectiveness, application optimization, longevity, resistance etc. (Segal and Glazer, 2000; Johnigk et al., 2004; Salame et al., 2010; Nimkingrat et al., 2013; Ulu and Susurluk, 2014). There are also new approaches like biochemical stimulation of EPN to improve different traits (Kaplan et al., 2012; Perret-Gentil et al., 2017). It is hoped that our results will have a positive contribution to the EPN application with drip irrigation. Nevertheless, more studies are essential for optimal EPN applications. It is important to expand biological control instead of synthetic chemicals and keep sustainable agriculture for the future. With feedback from new studies, different types of drippers or irrigation systems can be developed especially for EPN applications.

\section{Statement of Conflict of Interest}

Authors have declared no conflict of interest.

\section{Author's Contributions}

The contribution of the authors is equal.

\section{REFERENCES}

Arrington AE, Kennedy GG, Abney MR 2016. Applying insecticides through drip irrigation to reduce wireworm (Coleoptera: Elateridae) feeding damage in sweet potato. Pest Management Science 72 (6): $1133-1140$.

Conner JM, McSorley R, Stansly PA, Pitts DJ 1998. Delivery of Steinernema riobravis through a drip irrigation system. Nematropica 28 (1): 95-100.

Curran J 1992. Influence of application method and pest population size on the field efficacy of entomopathogenic nematodes. Journal of Nematology 24 (4S): 631-636.

Curran J, Patel V 1988. Use of A Trickle Irrigation System to Distribute Entomopathogenic Nematodes (Nematoda: Heterorhabditidae) for The Control Of Weevil Pests (Coleoptera: Curculionidae) Of Strawberries. Australian Journal of Experimental Agriculture 28 (5): 639643.

Ehlers R-U 2001. Mass production of entomopathogenic nematodes for plant protection. Applied Microbiology and Biotechnology 56 (5-6): 623-633.

Ehlers R-U 2005. Forum on safety and regulation (Nematodes as biocontrol agents, CABI: Wallingford, Eds. Grewal PS, Ehlers RU, ShapiroIlan DI) 107-114.

Ellsbury MM, Jackson JJ, Woodson WD, Beck DL, 
Stange KA 1996. Efficacy, application distribution, and concentration by stemflow of Steinernema carpocapsae (Rhabditida: Steinernematidae) suspensions applied with a lateral-move irrigation system for corn rootworm (Coleoptera: Chrysomelidae) control in maize. Journal of Economic Entomology 89 (1): 74-81.

Fife JP, Derksen RC, Ozkan HE, Grewal P 2003. Effects of pressure differentials on the viability and infectivity of entomopathogenic nematodes. Biological Control 27 (1): 65-72.

Gan-Mor S, Matthews GA 2003. Recent developments in sprayers for application of biopesticides - An overview. Biosystems Engineering 119-125.

Grewal PS 2002. Formulation and application technology (Entomopathogenic Nematology, CABI, Wallingford, Ed. Gaulger R) 265-287.

Johnigk S, Ecke F, Poehling M, Ehlers R-U 2004. Liquid culture mass production of biocontrol nematodes, Heterorhabditis bacteriophora (Nematoda: Rhabditida): improved timing of dauer juvenile inoculation. Applied microbiology and biotechnology 64 (5): 651-8.

Kaplan F, Alborn HT, von Reuss SH, Ajredini R, Ali JG, Akyazi , Stelinski, LL, Edison AS, Schroeder FC, Teal PE 2012. Interspecific nematode signals regulate dispersal behavior. PLoS ONE 7 (6): e38735.

Kaya HK, Gaugler R 1993. Entomopathogenic Nematodes. Annual Review of Entomology 38 (125): 181-206.

Kaya HK, Stock SP 1997. Techniques in insect nematology (Manual of Techniques in Insect Pathology, Elsevier, Ed. Lawrence A) 281-324.

Lacey LA, Grzywacz D, Shapiro-Ilan DI, Frutos R, Brownbridge M, Goettel MS 2015. Insect pathogens as biological control agents: Back to the future. Journal of Invertebrate Pathology 132: 1-41.

Nimkingrat P, Strauch O, Ehlers R-U 2013. Hybridisation and genetic selection for improving desiccation tolerance of the entomopathogenic nematode Steinernema feltiae. Biocontrol Science and Technology 23 (February 2014): 348-361.

Perret-Gentil A, Mirti A, Giurintano J, Sampson E, Gao X, Shapiro-Ilan D, Kaplan F 2017. Lack of pheromone reduces nematode dispersal (En annual meeting the american-phytopathological-society (aps), sanantonio, tx, aug 05-09, 2017). Phytopathology 107 (12, S): 110 .

Peters A 1996. The natural host range of Steinernema and Heterorhabditis spp. and their impact on insect populations. Biocontrol Science and Technology 6 (3): 389-402.

Raja RK, Hazir C, Gümüş A, Asan C, Karagöz M, Hazir S 2015. Efficacy of the entomopathogenic nematode Heterorhabditis bacteriophora using different application methods in the presence or absence of a natural enemy. Turkish Journal of Agriculture and Forestry 39 (2): 277-285.

Reed D, Reed G, Creighton C 1986. Introduction of entomogenous nematodes into trickle irrigation systems to control striped cucumber beetle, (Coleoptera: Chrysomelidae). Journal of Economic Entomology 79: 1330-1333.

Salame L, Glazer I, Chubinishvilli MT, Chkhubianishvili T 2010. Genetic improvement of the desiccation tolerance and host-seeking ability of the entomopathogenic nematode Steinernema feltiae. Phytoparasitica 38 (4): 359-368.

Sayinci B, Bastaban S 2008. The Role of Spray Units on Biological Control Agent Application. 39 (1): 151-157.

Segal D, Glazer I 2000. Genetics for improving biological control agents: the case of entomopathogenic nematodes. Crop Protection 19 (8-10): 685-689.

Shapiro-Ilan DI, Han R, Dolinksi C 2012. Entomopathogenic Nematode Production and Application Technology. Journal of nematology 44 (2): 206-17.

Stock SP, Hunt DJ 2005. Morphology and systematics of nematodes used in biocontrol (Nematodes as biocontrol agents, CABI, Wallingford, Eds. Grewal PS, Ehlers RU, Shapiro-Ilan DI) 3-43.

Susurluk IA, Ehlers R-U 2008. Field persistence of the entomopathogenic nematode Heterorhabditis bacteriophora in different crops. BioControl 53 (4): $627-641$.

Ulu TC, Susurluk IA 2014. Heat and desiccation tolerances of Heterorhabditis bacteriophora strains and relationships between their tolerances and some bioecological characteristics. Invertebrate Survival Journal 11: 4-10.

Wang X, Zhu H, Reding ME, Locke JC, Leland JE, Derksen RC, Spongberg AL, Krause CR 2009. Delivery of chemical and microbial pesticides through drip irrigation systems. Applied Engineering in Agriculture 25 (6): 883-893.

Wennemann L, Cone WW, Wright LC, Perez, Conant MM 2003. Distribution patterns of entomopathogenic nematodes applied through drip irrigation systems. Journal of Economic Entomology, 96, 287-291. 96 (2): 287-291.

Wright DJ, Peters A, Schroer , Fife JP 2005. Application technology (Nematodes as biocontrol agents, CABI, Wallington, Eds. Grewal PS, Ehlers RU, Shapiro-Ilan DI) 91-106.

Wright R, Witkowski J, Echtenkamp G, Georgis R 1993. Efficacy and Persistence of Steinernema carpocapsae (Rhabditida: Steinemematidae) Applied through a Center-Pivot Irrigation System Against Larval Corn Rootworms (Coleoptera: Chrysomelidae). Journal of Economic Entomology 86 (5): 1348-1354. 